\title{
PRIMING OF BRACHIARIA SEEDS WITH DIFFERENT SUGAR SOURCES AND CONCENTRATIONS ${ }^{1}$
}

\author{
THIAGO BARBOSA BATISTA ${ }^{2 *}$, ELIANA DUARTE CARDOSO BINOTTI ${ }^{3}$, FLÁVIO FERREIRA DA SILVA \\ BINOTTI ${ }^{3}$, MARCO EUSTÁQUIO DE SÁ ${ }^{4}$, TIAGO ALEXANDRE DA SILVA ${ }^{2}$
}

\begin{abstract}
Seed priming is a practice for improving the expression of seed physiological potential. Such technique consists of synchronizing and reducing the time of seed germination by controlled hydration. The aim of this study was to evaluate the effect of seed-priming with different sugar sources and concentrations on the physiological quality Urochloa brizantha seeds and initial seedling performance. Before treating, seeds were scarified chemically with concentrated sulphuric acid $\left(\mathrm{H}_{2} \mathrm{SO}_{4}\right)$ for 5 minutes to overcome physical dormancy. The experimental design was completely randomized in a 3 x 6 factorial scheme consisting of priming using three sugar sources (glucose, sucrose, and maltose) and six concentrations (zero [water control], $2 \%, 5 \%, 10 \%, 15 \%$, and $20 \%$ ), with four replicates. The seeds were primed by direct immersion for 2 hours at $25{ }^{\circ} \mathrm{C}$ and, after hydration, they were dried for moisture equilibrium recovery. Seed germination, vigor, viability, and initial seedling growth were evaluated. The results showed that glucose was the source able to promote beneficial effects on the germination of $U$. brizantha cv. MG-5 seeds. Moreover, the supply of glucose at the concentrations of 2 and $5 \%$ for physiological conditioning increased seedling dry phytomass.
\end{abstract}

Keywords: Urochloa brizantha. Glucose. Sucrose. Maltose. Direct immersion.

\section{CONDICIONAMENTO FISIOLÓGICO COM DIFERENTES FONTES E CONCENTRAÇÕES DE GLICÍDIOS EM SEMENTES DE BRAQUIÁRIA}

RESUMO - O condicionamento em sementes é uma prática capaz de possibilitar maior expressão do potencial fisiológico das sementes. Esta técnica permite a sincronização e redução do tempo de germinação das sementes através da hidratação controlada. O objetivo foi avaliar o efeito do condicionamento fisiológico em sementes de Urochloa brizantha com diferentes fontes e concentrações de glicídios na qualidade fisiológica de sementes e desempenho inicial das plântulas. Anterior a aplicação do priming as sementes foram submetidas a escarificação química com ácido sulfúrico concentrado $\left(\mathrm{H}_{2} \mathrm{SO}_{4}\right)$ por 5 minutos para remoção da dormência primária. $\mathrm{O}$ delineamento experimental foi o inteiramente casualizado, em esquema fatorial $3 \times 6$, constituído por condicionamento físiológico utilizando três fontes de glicídios (glicose, sacarose e maltose) e seis concentrações (zero [controle em água], 2\%, 5\%, 10\%, 15\% e 20\%), com quatro repetições. O condicionamento fisiológico utilizado foi via imersão direta por 2 horas a $25^{\circ} \mathrm{C}$ e, posteriormente a hidratação das sementes, foi realizada a secagem para a retomada da umidade de equilíbrio. Foi realizado teste de germinação, vigor, viabilidade das sementes e crescimento inicial de plântulas. A glicose como fonte de glicídio promoveu efeitos benéficos na germinação de sementes de U. brizantha cv. MG-5. O fornecimento de glicose nas concentrações de 2 e $5 \%$ pelo condicionamento fisiológico propiciaram incremento na fitomassa seca de plântulas.

Palavras-chave: Urochloa brizantha. Glicose. Sacarose. Maltose. Imersão direta.

\footnotetext{
*Corresponding author

${ }^{1}$ Received for publication in $03 / 21 / 2017$; accepted in $03 / 16 / 2018$.

Extracted from the research project of the second author.

${ }^{2}$ Department of Crop Science, Universidade Estadual Paulista "Júlio de Mesquita Filho", Botucatu, SP, Brazil; batistatb@hotmail.com ORCID: 0000-0002-6764-9600, tiago.at.agro@hotmail.com - ORCID: 0000-0002-8464-3905.

${ }^{3}$ Department of Agronomy, Universidade Estadual de Mato Grosso do Sul, Cassilândia, MS, Brazil; elianaduarte@uems.br - ORCID: 0000 -0003-1760-0363, binotti@uems.br-ORCID: 0000-0002-2248-8954.

${ }^{4}$ Department of Plant Science, Food Technology and Socio Economics, Universidade Estadual "Paulista Júlio de Mesquita Filho", Ilha Solteira, SP, Brazil; marcosa@agr.feis.unesp.br - ORCID: 0000-0002-0588-0356.
} 


\section{INTRODUCTION}

The use of Urochloa spp. in pasture areas have increased in Brazil, which stands out as the largest producer and exporter of tropical seeds worldwide (CARDOSO et al., 2014). Studies on this topic are of great agronomic importance since this species presents seed dormancy.

More recently, new studies have been developed to improve seed vigor such as by priming treatment. This technique consists of synchronizing and reducing the time of seed germination (MARCOS-FILHO, 2015) by controlled hydration, triggering the start of physiological processes (germination phases I and II), without radicle protrusion at phase III (LARA et al., 2014). These techniques aim at standardizing germination to establish an appropriate seedling stand.

Although not used on a large scale for major crops, seed priming has application in germplasm banks for small seed numbers (SILVA et al., 2016). Studies found in the literature have demonstrated that the priming of Brachiaria seeds increases the number of germinated seeds (CARDOSO et al., 2014), speed index (BINOTTI et al., 2014), and resistance to thermal stress (BATISTA et al., 2016a).

Sugars play an important role as energy supply during seed germination (MARCOS-FILHO, 2015) and in plant growth and development as both energy sources and signaling molecules (LEE et al., 2012). While studying the germination of Arabidopsis sp. seeds, Gibson, Laby and Kim (2001) observed that small concentrations of glucose and sucrose (nearly $0.0015 \%$ and $0.0185 \%$, respectively) were able to increase the number of germinated seeds.

In contrast, controversial hypotheses about the effect of high concentrations of sugars on seed germination can also be verified, such as the reporting by Eveland and Jackson (2011), who suggested that an increase in sugar concentration, e.g. glucose, may raise the levels of abscisic acid (ABA) and that both components tend to act synergistically during embryonic growth, thus hindering germination.

Little is known about the performance of sugars in seed germination and plant growth, there being only controversial and poorly comprehensive information on this subject. Thus, studies on the influence of sugars on seed germination are still necessary to clarify their performance in plant metabolism. Based on this, this study aimed to verify whether the use of sugars in the priming of Urochloa brizantha seeds influences seed quality and seedling initial performance.

\section{MATERIAL AND METHODS}

The experiment was conducted in 2013 at the Seed Analysis Laboratory of the Universidade Estadual de Mato Grosso do Sul (State University of Mato Grosso do Sul), in Cassilândia, Mato Grosso do Sul state, Brazil, using U. brizantha cv. MG-5 seeds from the 2011/12 growing season. The initial physiological characteristics of the seeds were: water content $=11 \%$; total germination $=51 \%$; dormant seeds $=38 \%$.

Prior to treatment, seeds were chemically scarified with concentrated sulphuric acid $\left(\mathrm{H}_{2} \mathrm{SO}_{4}\right)$ for 5 minutes to overcome physical dormancy and, after that, they were washed and placed in deionized running water and naturally dried for $24 \mathrm{~h}$ (BATISTA et al., 2016b).

The experiment followed a completely randomized design (CRD) in a $3 \times$ x 6 factorial scheme, with four replicates for each treatment. The first factor consisted of seed priming with three sugar sources (glucose, sucrose, and maltose), while the second was six different concentrations of each sugar source [zero (water control), 2\%, 5\%, 10\%, 15\% and $20 \%]$.

Seeds were primed using hydration at $25{ }^{\circ} \mathrm{C}$ for $2 \mathrm{~h}$. After priming, the seeds were dried at room temperature for $24 \mathrm{~h}$ (CARDOSO et al., 2014). Then, pure seeds were selected to perform physiological tests.

Four subsamples of 50 seeds were used for a germination test. The seeds were distributed into plastic germination boxes, using as substrate blotting paper moistened with 2.5 times its dry mass. The counts were performed on the $7^{\text {th }}$ (first germination count) and on the $21^{\text {st }}$ (total germination) days after sowing (DAS), as established by the Brazilian Rules for Seed Analysis (BRASIL, 2009).

Germination speed index was calculated by the sum of the number of germinated seeds at each day, divided by the number of days between sowing and germination adapted from (MAGUIRE, 1962).

After germination test, the remaining seeds (viable and unviable) were submitted to tetrazolium test, according to a standard method for Urochloa (Brachiaria) seeds (BRASIL, 2009). It consisted of counting the number of viable and remaining unviable seeds from the germination test.

An electrical conductivity test was also carried out using four subsamples of 50 seeds, weighed to at least two decimal places. The seeds were imbibed in $75 \mathrm{~mL}$ of deionized water and maintained at $25{ }^{\circ} \mathrm{C}$ for 24 hours. Then, the soaking solution was measured for electrical conductivity (EC), with results expressed in $\mu \mathrm{S} \mathrm{cm}^{-1} \mathrm{~g}^{-1}$ (VIEIRA; KRYZANOWSKI, 1999).

The emerged plants were recorded until emergence stabilization, calculating the percentage for the $7^{\text {th }}$ (first emergence count) and for the $28^{\text {th }}$ (total emergence) DAS. The results were expressed in percentage of emerged seedlings.

Emergence speed index (ESI) was also 
estimated by the sum of the number of emerged seeds at each day, divided by the number of days between sowing and emergence adapted from (MAGUIRE, 1962), until the number of emerged seedlings stabilized, within a 28-day period after sowing.

At the end of emergence test, twenty normal seedlings from each repetition were randomly removed, maintaining the root system intact, and then shoot and root lengths were measured.

After washed and dried in a forced-air oven at $65^{\circ} \mathrm{C}$ for $72 \mathrm{~h}$, the dry phytomass of these seedlings was randomly evaluated using an analytical scale, with values expressed in $\mathrm{mg}$ seedling ${ }^{-1}$.

All the data were analyzed through analysis of variance (ANOVA) using the $\mathrm{F}$ test. In case of significant differences among treatments, the Tukey's comparison test $(\mathrm{p}<0.05)$ was applied for sugar sources and a regression adjustment for the sugar concentrations. For the remaining unviable seeds, the data were analyzed after normalization by transforming them to square root arcsine $(\mathrm{x} / 100)$.

\section{RESULTS AND DISCUSSION}

An interaction among the studied factors was verified for total germination and remaining unviable seeds (Figure 1 and 2). By comparing priming with glucose and maltose at concentrations of 2 and $10 \%$, germination percentage increased by 84 and $87 \%$, respectively. And, when compared with sucrose at $15 \%$, this increase was $85 \%$. Moreover, a positive linear equation was found to fit the glucose data, indicating that this source promoted a linear increase in the germination of $U$. brizantha cv. MG -5 seeds (Figure 1).

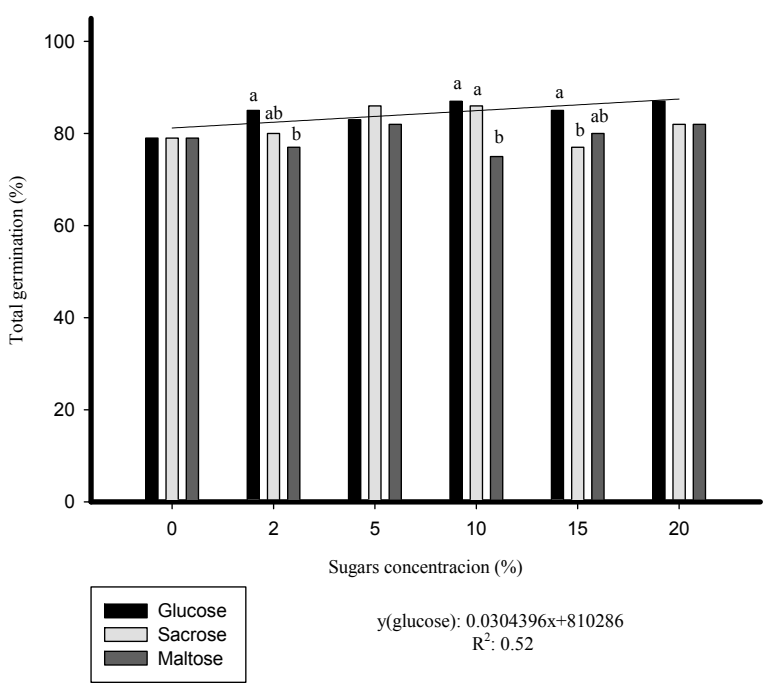

Figure 1. Effect of priming with different sugar sources and concentrations on total germination of $U$. brizantha seeds. Means followed by different letters in the column differ statistically from each other by the Tukey's test at $5 \%$ probability.

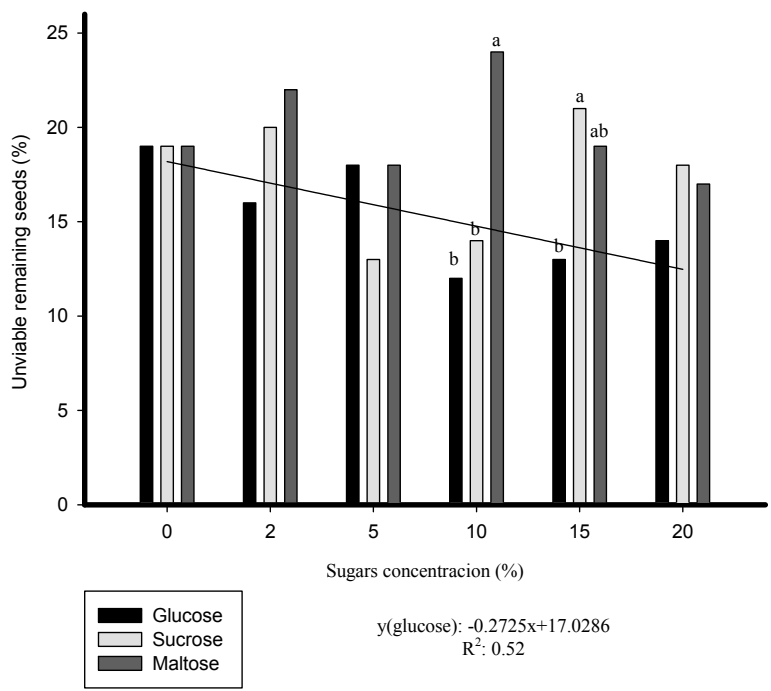

Figure 2. Effect of priming with different sugar sources and concentrations on remaining unviable seeds of $U$. brizantha. Means followed by different letters in the column differ statistically from each other by the Tukey's test at $5 \%$ probability. 
When comparing the use of glucose and sucrose at $10 \%$ to maltose at $24 \%$, the number of remaining unviable seeds decreased in $11 \%$ and $14 \%$, respectively. In addition, the use of $15 \%$ glucose provided a lower number of dead seeds $(13 \%)$ if compared to $21 \%$ sucrose, but not differing from maltose. For this variable, a negative linear equation was found to fit glucose data, showing that increasing concentrations of this source decrease the number of dead seeds (Figure 2).

The benefits of priming by direct immersion for $U$. brizantha seeds have already been reported in the literature, both with water or other chemical agents (BATISTA et al., 2016a; BATISTA et al., 2016b). In this study, there was an additional benefit to the effect of priming using glucose during conditioning by direct immersion under germination.

In studies conducted with Arabidopsis spp. seeds, Arenas-Huertero et al. (2000) observed the influence of glucose on plant development and seed germination, and Price et al. (2003) pointed out that this sugar source reduces the effect of $\mathrm{ABA}$, accelerating germination. Such reduction of ABA is essential for germination to occur since the high concentration of this hormone inhibits embryo development (OLIVEIRA JÚNIOR et al., 2009). These findings corroborate the results obtained in the present study for $U$. brizantha seeds, in which increasing glucose concentrations improved the percentage of germinated seeds and, if compared to the other sugar sources, this effect may be even higher for certain concentrations. In addition, since the primary dormancy of $U$. brizantha seeds had already been overcome by chemical scarification, glucose was responsible for promoting the germination process and preventing a secondary dormancy mechanism, thus leading to greater germination when supplied during the priming.

Increases in germination rate and speed were observed at 7 days when glucose and sucrose were used as a sugar source in conditioning if compared to the use of maltose (Table 1).

Table 1. Effect of priming with different sugar sources and concentrations on the first germination count (FGC), germination speed index (GSI), remaining viable seeds after germination test, and electrical conductivity for $U$. brizantha seeds.

\begin{tabular}{|c|c|c|c|c|}
\hline \multirow{3}{*}{ Sugar sources } & \multicolumn{2}{|c|}{ Germination } & \multirow{2}{*}{ Remaining viable seeds } & \multirow{2}{*}{ Electrical conductivity } \\
\hline & FGC & & & \\
\hline & -----(\%)----- & & -----(\%)----- & $--\left(\mu \mathrm{S} \mathrm{cm} \mathrm{cm}^{-1} \mathrm{~g}^{-1}\right)--$ \\
\hline Glucose & $80 \mathrm{a}$ & $5.87 \mathrm{a}$ & 1 & $30.66 \mathrm{ab}$ \\
\hline Sucrose & $79 \mathrm{a}$ & $5.74 \mathrm{a}$ & 0 & $33.33 \mathrm{a}$ \\
\hline Maltose & $76 \mathrm{~b}$ & $5.52 \mathrm{~b}$ & 0 & $29.61 \mathrm{~b}$ \\
\hline \multicolumn{5}{|l|}{ Sugar concentrations $(\%)$} \\
\hline 0 & 77 & 5.52 & 2 & 41.90 \\
\hline 2 & 78 & 5.65 & 0 & 26.59 \\
\hline 5 & 80 & 5.85 & 0 & 27.28 \\
\hline 10 & 81 & 5.83 & 0 & 30.74 \\
\hline 15 & 77 & 5.60 & 1 & 28.78 \\
\hline 20 & 80 & 5.80 & 0 & 31.90 \\
\hline Source & $7.51^{* *}$ & $8.21^{* *}$ & $0.94^{\mathrm{ns}}$ & $4.69^{* *}$ \\
\hline Regression adjustment & ns & ns & Ns & $\mathrm{ns}$ \\
\hline $\mathrm{CV}(\%)$ & 5.68 & 5.33 & 7.29 & 17.03 \\
\hline
\end{tabular}

Means followed by different letters in the column differ statistically from each other by the Tukey's test at $5 \%$ probability; ${ }^{* *}$ Significant at $1 \%$ probability; ${ }^{\text {ns }}$ non-significant; $\mathrm{CV}$ - coefficient of variation.

But unlike these results, when studying the control of plant development and gene expression by using sugar, Gibson (2005) reported that increasing levels delayed the germination of Arabidopsis seeds. Interestingly, the results of this study showed a contrary effect on $U$. brizantha seeds since sugar addition during priming had no negative effect on germination speed.

By the EC test, the use of maltose showed a decrease in the content of leachates in the imbibition solution compared to sucrose use, but not differing from glucose (Table 1). Such a reduction indicates a greater integrity of cell membranes and has a direct influence on seed vigor. Therefore, the EC test was inefficient in predicting the vigor of seeds conditioned in glucose, as the first germination count and GSI test showed increases when using glucose and sucrose.

The studied factors had no influence on the variables first emergence count, total emergence, and ESI (Table 2). However, shoot length was higher using sucrose compared to the use of maltose, but 
not differing from glucose. Yet the root length data were adjusted to a quadratic equation in response to the used concentrations, with a maximum value when applying $11.58 \%$ of the tested sugars (Table 2).

Corroborating the results of this study, Lee et al. (2012) found no inhibition of root growth for Arabidopsis mutants when in the presence of $6 \%$ glucose. However, at $1 \%$ glucose, the results suggested a reduction in the cell division of the root meristem, which results in a delay in root growth. Therefore, higher sugar concentrations could benefit plant growth, the longest roots were found at a sugar concentration of $11.58 \%$.

Table 2. Effect of priming with different sugar sources and concentrations on the first emergence count (FEC), total emergence (TE), emergence speed index (ESI), and shoot and root length of $U$. brizantha seedlings.

\begin{tabular}{|c|c|c|c|c|c|}
\hline \multirow{3}{*}{ Sugar sources } & \multicolumn{3}{|c|}{ Emergence } & \multicolumn{2}{|c|}{ Length } \\
\hline & FEC & $\mathrm{TE}$ & \multirow{2}{*}{ ESI } & Shoot & Root \\
\hline & \multicolumn{2}{|c|}{----------(\%)----------- } & & \multicolumn{2}{|c|}{$--\left(\mathrm{cm}\right.$ seedling $\left.{ }^{-1}\right)--$} \\
\hline Glucose & 74 & 76 & 5.37 & $13.15 \mathrm{ab}$ & 15.84 \\
\hline Sucrose & 75 & 78 & 5.53 & $13.76 \mathrm{a}$ & 15.38 \\
\hline Maltose & 75 & 77 & 5.47 & $12.33 \mathrm{~b}$ & 15.57 \\
\hline \multicolumn{6}{|l|}{ Sugar concentrations (\%) } \\
\hline 0 & 74 & 77 & 5.42 & 12.12 & 14.32 \\
\hline 2 & 77 & 80 & 5.63 & 13.74 & 15.83 \\
\hline 5 & 74 & 76 & 5.39 & 13.50 & 15.87 \\
\hline 10 & 72 & 73 & 5.26 & 12.80 & 16.06 \\
\hline 15 & 77 & 79 & 5.58 & 12.74 & 15.88 \\
\hline 20 & 75 & 78 & 5.45 & 13.58 & 15.61 \\
\hline Source & $0.45^{\mathrm{ns}}$ & $0.38^{\mathrm{ns}}$ & $0.56^{\mathrm{ns}}$ & $5.51^{* *}$ & $0.80^{\mathrm{ns}}$ \\
\hline Regression adjustment & ns & $\mathrm{Ns}$ & Ns & ns & $\mathrm{QR}^{(1)}$ \\
\hline $\mathrm{CV}(\%)$ & 9.58 & 9.82 & 9.69 & 11.40 & 8.19 \\
\hline
\end{tabular}

Means followed by different letters in the column differ statistically from each other by the Tukey's test at $5 \%$ probability; $* *$ Significant at $1 \%$ probability; ns non-significant; $\mathrm{QR}$ quadratic regression; ${ }^{(1)} \mathrm{y}=-0.01054076 \mathrm{x}^{2}+0.2443329 \mathrm{x}+14.807487$ and $\mathrm{R}^{2}=0.68 ;$ C.V. - coefficient of variation.

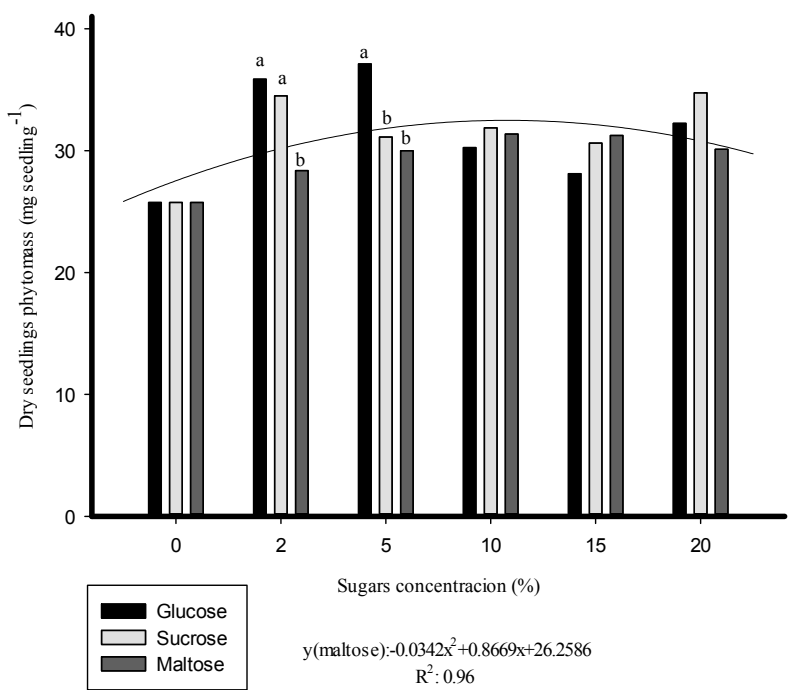

Figure 3. Effect of priming with different sugar sources and concentrations on the dry phytomass of $U$. brizantha seedlings. Means followed by different letters in the column differ statistically from each other by the Tukey's test at $5 \%$ probability. 
Interactions among the studied factors were verified for seedling dry phytomass (Figure 3 ). At a concentration of $2 \%$, glucose and sucrose showed higher accumulation of dry phytomass (35.87 and $34.50 \mathrm{mg}$ seedling ${ }^{-1}$, respectively) when compared to maltose $\left(28.37 \mathrm{mg}\right.$ seedling $\left.{ }^{-1}\right)$. For a concentration of $5 \%$, the highest dry phytomass accumulation was verified when using glucose (37.12 $\mathrm{mg}$ seedling $\left.{ }^{-1}\right)$ against the values of $31.12 \mathrm{mg}^{-1}$ seedling ${ }^{-1}$ and $30 \mathrm{mg}$ seedling ${ }^{-1}$ by the use of sucrose and maltose, respectively. Data on maltose concentrations were adjusted to a quadratic equation with maximum dry phytomass reached when using a concentration of $12.68 \%$ (Figure 3).

As it acts on seed germination, glucose may favor seedling performance (PRICE et al., 2003). Eveland and Jackson (2011) found that carbohydrates (sugars) are essential in basic processes required for plant growth. The findings of this study reinforce these claims since there was an increase in the dry phytomass of $U$. brizantha seedlings conditioned with glucose.

The sugar sources used in the seed-priming technique promoted germination and initial development of $U$. brizantha cv. MG-5 plants, evidencing their potential to obtain seeds with a higher physiological quality.

\section{CONCLUSIONS}

The priming of seeds of Urochloa brizantha cv. MG-5 using glucose as a source of sugar promoted increases in germination rate, and the concentrations of 2 and $5 \%$ glucose provided increases in the dry biomass of its seedlings.

\section{REFERENCES}

ARENAS-HUERTERO, F. et al. Analysis of Arabidopsis glucose insensitive mutants, gin5 and gin6, reveals a central role of the plant hormone ABA in the regulation of plant vegetative development by sugar. Genes and Development, New York, v. 14, n. 16, p. 2085-2096, 2000.

BATISTA, T. B. et al. Priming and stress under high humidity and temperature on physiological quality of Brachiaria brizantha cv. MG-5 seeds. Acta Scientiarum. Agronomy, Maringá, v. 38, n. 1, p. 123-127, 2016a.

BATISTA, T. B. et al. Appropriate hydration period and chemical agent improve priming in brachiaria seeds. Pesquisa Agropecuária Tropical, Goiânia, v. 46, n. 3, p. 350-356, 2016 b.

BINOTTI, F. F. S. et al. Tratamentos pré-germinativos em sementes de Brachiaria. Revista Brasileira de Ciências Agrárias, Recife, v. 9, n. 4, p. 614-618, 2014

BRASIL. Ministério da Agricultura, Pecuária e Abastecimento. Regras para análise de sementes. Ministério da Agricultura, Pecuária e Abastecimento. Secretaria de Defesa Agropecuária. Brasília, DF: Mapa/ACS, 2009. 395 p.

CARDOSO, E. D. et al. Desempenho físiológico e superação de dormência em sementes de Brachiaria brizantha submetidas a tratamento químico e envelhecimento artificial. Semina: Ciências Agrárias, Londrina, v. 35, n. 1, p. 21-38, 2014.

EVELAND, A. L.; JACKSON, D. P. Sugars, signalling, and plant development. Journal of Experimental Botany, Lancaster, v. 63, n. 9, p. 3367-3377, 2011.

GIBSON, S. I. Control of plant development and gene expression by sugar signaling. Plant Biology, Saint Louis, v. 8, n. 1, p. 93-102, 2005.

GIBSON, S. I.; LABY, R. J.; KIM, D. The sugarinsensitive1 (sis1) mutant of Arabidopsis is allelic to ctr1. Biochemical and Biophysical Research Communications, Martinsried, v. 280, n. 1, p. 196203, 2001

LARA, T. S. et al. Potassium nitrate priming affects the activity of nitrate reductase and antioxidant enzymes in tomato germination. Journal of Agricultural Science, Toronto, v. 6, n. 2, p. 72-80, 2014.

LEE, S. A. et al. Analysis of Arabidopsis glucose insensitive growth mutants reveals the involvement of the plastidial copper transporter PAA1 in glucoseinduced intracellular signaling. Plant Physiology, Urbana, v. 159, n. 3, p. 1001-1012, 2012.

MAGUIRE, J. D. Speed of germination aid in selection and evaluation for seedling and vigour. Crop Science, v. 2, n. 2, p. 176-177, 1962.

MARCOS-FILHO, J. Fisiologia de sementes de plantas cultivadas. 2 . ed. Londrina, PR: ABRATES, 2015. $660 \mathrm{p}$

OLIVEIRA JÚNIOR, L. F. G. et al. Insulina e glicose como moduladores do desenvolvimento de plântulas de milho doce (Su1). Acta Botanica Brasilica, São Paulo, v. 23, n. 3, p. 751-755, 2009.

PRICE, J. et al. Mechanisms of glucose signaling during germination of Arabidopsis. Plant Physiology, Urbana, v. 132, n. 3, p. 1424-1438, 2003. 
SILVA, T. A. et al. Condicionamento fisiológico em sementes de soja, componentes de produção e produtividade. Ciência Rural, Santa Maria, v. 46, n. 2, p. 227-232, 2016.

VIEIRA, R. D.; KRYZANOWSKI, F. C. Teste de condutividade elétrica. In: KRYZANOWSKI, F. C.; VIEIRA, R. D.; FRANÇA NETO, J. B. (Eds.). Vigor de sementes: conceitos e testes. Londrina: ABRATES, 1999. cap. 4, p. 1-26. 